\title{
The Buncombe County Case
}

\author{
by Ainsley A. Whitman * \\ Librarian, University of North Carolina \\ at Asheville
}

A review of the Buncombe County case may prove helpful if you will consider solutions to the various problems we encountered. Please feel free to criticize anything we may have done, or said, or left undone. Although this is a school-related problem I believe there are elements that may be of interest to many librarians. I have chosen to make our story quite personal; revealing my random thoughts, emotions, and opinions. In short, to suggest what it "feels like" to be involved in a censorship movement. These are my reactions; the superintendent of schools or Christine Miller, the library supervisor might give impressions that are quite different than mine.

It began the evening of March the 26th. Going to the grocery to buy some cottage cheese for little dog Holly. She loves her bedtime snack. Just about to pass the newspaper rack. Something like ESP whispers, "be sure to see the headlines tonight!" There it was, "Education Board Member Refuses To Return Books To Two Libraries." Horrified, I read on: "A member of the Buncombe County Board of Education refused today to return books she had checked out of two high school libraries, vowing to continue until all of the books she considers 'trash' are removed from the school shelves. Mrs. Edna Roberts said she had students check out eight books at North Buncombe High School for her including The Learning Tree, Andersonville, Of Mice And Men, Catcher In The Rye, Grapes Of Wrath, Jory and two others she said she did not remember the

\footnotetext{
*Presented at the Workshop on Intellectual Freedom, The North Carolina Library Association, WinstonSalem, October 31, 1973.
}

names of. She said she had read only one book, Jory, herself. Mrs. Roberts said she had 'no idea' where the list came from. 'She got hers,' she said, 'from a PTA group.' She believes the movement is 'all over the country, and she thinks 'there are three groups doing some research in South Carolina.'"

"School Superintendent Fred H. Martin said he did not know of the action in advance. The board meets at 7:30 p.m. today ... for a work session to go over matters that will be covered at the reg. ular meeting Wednesday morning. Mrs. Roberts said she plans to bring up the subject at tonight's meeting. 'What we need is a paid person who could look at these books before they are put in the libraries,' she said. 'I know they've got plenty of others!' Asked what she plans to do if the board does not take action, Mrs. Roberts said she would return to handling the challenge 'down at the library level.' She said she would be going into each school library, including those at the elementary level, and making an on-site inspection of the kind of books on the shelves."

The article contains comments from other board members that may be summarized by Mrs. Cecil's comment, "I do not think this is the proper way to go about it." In Z. R. Sheppard's words, "I wonder what right somebody would have to do that?" Dr. W. E. Farmer stated, "II's frightening when people start talking about censoring books."

At home now, talking it over with Joyce. We agree a dangerous movement has been launched. "Remember," she says, "how I always fared the Christian Action 
League would strike out against our county library in Lenoir. I wonder why they never did." Wish we could attend the board meeting tonight, but for so long we've looked forward to hearing the Cleveland Symphony. At the auditorium now, the music is "out of this world." Every once in awhile you're distracted. Can't help wondering what's going on over at the courthouse.

Back home we talk about it all over again. What possibly could anyone object to in Of Mice And Men or Andersonville? In bed you toss and turn, toss and turn. You keep thinking, someone ought to speak out against censorship. Who can do it? Can Christine do it? Board members are extremely powerful. Mrs. Roberts might try to get her fired. Knowing Fred, the superintendent you're sure he opposes. You're certain the two board members you know are against censorship. But they need reinforcement. They're likely to be bombarded by a noisy mob. How much pressure can they withstand? Wondering now if you should speak out. Someone's got to. Suppose you did, what would you say? You mull it over, backwards and forwards; sleep eludes you.

The next morning while Joyce prepares breakfast you read aloud from the morning paper, "Parents Attack 'Pornographic' library Books." "Approximately 30 parents of Buncombe County school children appealed to the county board of education at a work session Monday night to bar 'pornography' from school libraries. Mrs. Edna Roberts, a board member, opened the discussion on pornography and said she was very much concerned over the types of books found in school libraries. Mrs. Mimi Cecil, also a board member, noted that a number of highly complex questions had been raised and that time Would be required to study them. Mrs. Roberts asked, "What's so complex about it, Mrs. Cecil? There are plenty of good books." Mrs. Hayes a visitor, stressed that the problem is not solely a local one, but must, she said, be approached on a Statewide basis. A number of legislators are attempting to do something about the quality of reading materials, Mrs. Hayes said, noting that such a bill was introduced in the last session, but died in committee. Another parent suggested that the perverts who roam the roads, the dope addicts and degenerates who push dope may have sneaked these books into the libraries.' Several parents told the board they were not particularly concerned about the classics even though there were certain parts they would prefer their children not read. The parents asked that the board appoint a committee to censor the school libraries, "and do it right" and volunteered to "help."

At the office you talk it over with Dean and James. What should be done? You call Christine and find she'll be in a meeting all day. You call Ken at the public library but he's in hiding working on his budget. You call Frances at the city schools office and discuss it with her. You call an official in Raleigh for advice, only to learn he will be away all week. Later you learn you called the wrong person! You decide to speak out. If you're to be ready by eight tomorrow you've got to hurry. You write and re-write. Dean and James listen patiently and offer valuable advice.

The next morning only a few persons attend the board meeting. You are reading your statement now. Notice the TV cameraman, he is focusing on the sign below the clock that reads, "Asheville The All American City." All this has really changed our image! You are telling them about your training and experience. How much better it would have been if there had been time to get your architect friend, Ned, to talk; or his wife. She has done volunteer work among the mountain people for a long time. She possibly could have convinced the board how desperately the young people here need to have books that will give them a broader perspective of the world beyond the mountains. After quoting the law about stealing books from libraries you inquire if the board should ask the attorney general if Mrs. Roberts had contribuited to the delinquency of minors by arranging for students to check out books for her and then to lie to the librarians by reporting the books 
lost. By citing several examples, you express the opinion she has not compensated the county by merely paying the list price for the books. You oppose the procedure of judging a work by removing limited passages out of context. You close with a quotation from President Eisenhower, presented to the American Library Association meeting in Los Angeles, that seems appropriate for these days when he wrote, ". . . But we know that freedom cannot be served by the devices of the tyrant. As it is an ancient truth that freedom cannot be legislated into existence, so it is no less obvious that freedom cannot be censored into existence. And any who act as if freedom's defenses are to be found in suppression and suspicion and fear confess a doctrine that is alien to America. The libraries of America are and must remain the home of free, inquiring minds. To them, our citizens - of all ages and political persuasions - must ever be able to turn with clear confidence that they can freely seek the whole truth, unwarped by fashion and uncompromised by expediency. For in such whole and healthy knowledge alone are to be found and understood those majestic truths of man's nature and destiny that prove, to each succeeding generation, the validity of freedom."

(signed) Dwight D. Eisenhower.

A student comments, quoting Webster, that "pornographic" has been defined as "writing ... intended to arouse sexual desire." He states that none of these books aroused such a feeling within him. On the contrary, he says, he believes his life has been enriched by having read the books and that many of his fellow students, for whom he is the spokesman, hold the same opinion. Another student agrees, stating the great majority of his fellow students are opposed to the actions of a few students in removing books for the purpose of censorship. He says that students are not penalized for refusing to read any particular book they find objectionable. They are given a choice of other books to read.

As James and Dean leave the room with you, a schoolman thanks us for coming. "They really gave us holy hell Monday night," he says. A radio man asks if you will grant an interview. "Yes, be glad to." We go to a nearby office where a secretary allows him to put his gear on a corner of her desk. "Now I am ready," he says. "Mr. Whitman, what was the most important thing you said today?" "I believe this was my reading of the school library bill of rights that was endorsed by the American Library Association, representing over 30,000 librarians of the United States. A considerable amount of time and effort by educators was devoted to the preparation of this excellent statement of criteria for the selection of materials for our libraries. This was not a policy devised overnight. Hours and hours and hours of thought and discussion is reflected in this outstanding expression of policies." "Do you believe the board will do anything with your charges against Mrs. Roberts?" "No, I don't think so. After all, they have to live with her for seven more years!" "Thank you, Mr. Whitman." "Thank you." Then you are out in the hall. There are the students, including the two boys who spoke with such conviction. To them you say, "Oh thank you, young people, for coming, you did so well." They say they are glad you spoke too and invite you to visit their school. "You will be glad to," you reply, "it is so very, very important you young people have the opportunity to read the very best books obtainable. Your voice quivers as you repeat, "It is so very, very important." One of the boys grabs you by the arm and says reassuringly, "Mr. Whitman, everything is going to turn out all right." As you leave, you pray to God that it will.

Back at the office the phone rings; this is Luther Brown, CBS Morning News ...

Atlanta. He asks all kinds of questions. You wonder if you said the right thing and whether he will ever use any of the information yau gave him. You hurry home from work. Don't want to miss seeing yourself on the five-thirty news. Now the announcer is talking about the Buncombe Case. Something's gone wrong with the video tape. Don't see yourself 
at all; instead there is a picture of a damned old school bus. In the evening paper Mrs. Roberts issues a revised version of how she secured books belonging to the libraries. "I did not request any child in Buncombe County to check out any books. She said she did not know who the students were and did not know the parents of the children." This is an entirely different story than the first version. What is the truth?

One day that gorgeous secretary from another department comes in to tell you she visited another office and the gal there said, "She didn't see how that nice Mr. Whitman could do such a horrible thing as he did, it was just horrible." Miss Gorgeous thought I might like to see some literature the gal gave her from a group called the "AFA." You look over the mimeographed sheets presenting excerpts from the books mentioned by Mrs. Roberts. Among the statements upholding censorship you read, "Action has become necessary for intervention in the sphere of public education because of the extreme abuse of academic freedom, wherein perverted thinking, (however talented) is allowed to hold sway in ... the lives of our children. Censorship is not a bad word. The bad words are in the library books. There has always been a need to censor and delete, to use good judgment, where a young mind is concerned. This is a part of training at home and at school if we care at all about their moral climate. Parents should decide - not the pupils or educators, when it has (descended) to this level. Is there a direct relationship between the low-calibre of materials used in the public school system and the overall moral decadence in our nation? Responsible people should start (and they are) doing something about the crisis in education, otherwise we cannot complain."

You wonder about "AFA" Later you learn the full name is "The Answer For America, II Chronicles 7:14."

One day you answer the phone and a man says, "Mr. Whitman, I can't tell You who I am, I think you should know that tomorrow night there will be a large delegation from the Red Oak Community and other areas of the county who will attend the work sessions of the county school board. You thank him for calling and alert the superintendent's office. We call Ken Brown and he promises to help secure speakers for our side. The AAUP on campus promises their support. Although it is a bitterly cold night, there are over two hundred people present. The meeting is moved to the largest court room. The audience is packed with members of the Christian Action League. Zora Hayes, an unsuccessful candidate for the legislature on the American party ticket, distributes mimeographed materials labeled Premise One and Premise Two. You scan the papers quickly. Premise Two is a dirty trick. It comes through to you now, loud and clear. One of the purposes behind the book-banning movement is to embarrass the superintendent and to aid their campaign to block his re-appointment. The chairman recognized Mrs. Roberts. She reviews her efforts to rid the libraries of pornography and presents Premise One, which reads in part as follows:

". . . I believe that I have a responsibility to those who have elected me to point out areas wherein our local school system might be improved. Such an area is our school libraries. . . . Regardless of what may be found suitable in other counties, in other states ... it is the climate in Buncombe County that I am most concerned with. It matters not how many publishers' review boards insist that such-and-such a publication is number one on that month's selection; nor for how many years any publicaton may have held a place of esteem which some have insisted entitle it be termed a 'classic' and thus be required reading for all who could lay claim to culture - if these publications are offensive to my people - and they are also your people - these publications must go! . . Be it resolved that the Board of Education of Buncombe County employ a part-time librarian (a retired, proven competent, judge) to evaluate the quality of books and materials recommended for purchase by the instructional media personnel as reading materials for 
grades kindergarten thru 12; that this, qualified individual work directly under the office of the superintendent, having responsibility for liaison between that office and those on the administrative staff of each county school to whom falls the responsibility for books selection; that each county school appoint a committee of parents to assist the librarian of that school in the reading and selection of books for that library; that those persons charged with the responsibility of purchasing books for use in the school submit request for these purchases over their own signature: ... that this board investigate the means for securing an appropriation immediately from the current session of the North Carolina General Assembly "To improve the quality of materials in our school libraries.

"Be it further resolved... that to so insure the freedom of choice at all levels, it shall be the perrogative of any parent to counter with a refusal any assignment of reading matter which that parent or parents - or student - finds in any way objectionable: That his objection shall be made known in writing in the form of a signed statement whose wording shall be developed by. . . ."

"The library supervisor, to whom all such forms shall be sent for guidance in the selective process... that books which contain passages objectionable to parents as unsuitable reading material for their children, and which are at this time on the shelves of any county school, be summarily and without delay brought together in one place and collectively disposed of in whatever manner may be determined by this board . . . that the new position of library supervisor be the receptacle of a constant input of recommendations regarding quality reading and instructional materials from interested parents . . . and that this resolution be adopted to become effective as of this meeting."

"Respectfully submitted, Mrs. Edna R. Roberts."

How ironic! In concluding her remarks Mrs. Roberts reads the same quotation from Eisenhower that you had presented to the board. Imagine her condemning the censors!! A Black minister and radio personality leads the attack with an emotional appeal of considerable impact. Several in the audience are yelling, "Pour it on, brother, pour it on!" One layman screams, "Why wait, why wait, take 'em out tonight! We're already too late, let's take 'em out tonight." A psychologist is speaking for our side, but his remarks are met with such scorn you fear for his safety.

A fundamentalist street corner preacher goes yelling, ranting and raving up and down the aisle. He tells how he took a similiar fight "clean to the governor of Georgia." One man threatens the life of any teacher who assigns any of these "dirty books" for his child to read. One mother says she would rather have her child live in ignorance than to read "stuff like this." One high school boy expresses his re vulsion in reading one of these books and says he has no intention of reading any others. The dean of men from the university makes a brief statement. You point out that no part-time librarian, or even the committee members, would have time to read all the books; and the whole idea of the volunteer committee is unworkable. You stress the fact that it is undesirable to reject books by merely quoting words and passages out of context citing His Eye Is On The Sparrow, as an example. These observations trigger an attack against librarians and intellectuals that continues on and on until finally the chairman remarks the board must turn to other business.

Only a few persons attend the meet ing of the board on Wednesday. The dirty trick of Premise Two fails; Superintendent Martin is re-elected. The board turns to the problem of censorship. Mrs. Roberts moves that Premise One be adopted. The motion fails for want of a second. The Rev. Jeff Kesterson, President of the Ministerial Alliance, makes a brief statement opposing censorship and requests the board to take a reasoned, moderate stand. Mrs. Ann Robb presents the following, "The Asheville League of Women Voters wishes to state its support of the operation of the Buncombe County school libraries and their selection of library books. We sup. 
Port the standards and objectives of the American Library Association, and agree that the responsibility for the selection of instructional materials is best delegated to the professionally trained personnel employed by the school system - as is now the case." The board, With Mrs. Roberts abstaining, votes to re-affirm its policies for selection. At least for the moment, victory is ours!

One day you're in Durham. My gosh, you haven't been here since you were a handsome sergeant in the 89th Infantry Division in World War II. The traffic is heavy. You're on the main street. My Lordie, there's the same old public library you used to visit thirty years ago! It looks even worse now than it did then. Poor George Linder, he's worked so damned hard to get them a new library. You find the motel and spend the evening reading. Then you call Joyce. "Are you all right?" "Yes, I'm all right." "I haven't been here for so long, just been thinking about old times in the army." "Good night." "Good night, honey, I love you!" As you turn out the light your thoughts rush back to that bitterly cold morning at dawn so many years ago. You're marching down an icy street. You fall down. Your pack is so heavy you can't get up by yourself. Your buddies help you. You're really messed up the marching line this time! You help one another on to the troop train. You're already twenty-nine hundred miles away from your beloved home by the Golden Gate and a thousand emotions are crowding in upon you. The train is moving now. The skyline of Durham fades away. Soon you're in combat; walking amidst the rubble of an ancient and once beautiful city where one man began it all by guiding his people to burn their books, to take away the people's right to know, to destroy their freedom of inquiry, to divest them of their choice in the selection of the written word. Three decades have passed. You're in Durham from the "Land of the Sky" to attend a meeting of the Intellectual Freedom Committee. What message do you bring them from the mountains? "Times" reporter Mike Boyd says he was told that burning the books on the courthouse steps had been jokingly discussed by two of the protestors." Some joke! Some joke!

One day the fifth columnist you have planted in the AFA brings their latest publication. They are at it again, quoting the same excerpts from books. They are glorying in their defeat of the Women's Liberation Amendment. A lot of material is presented about prayer in schools. According to them "great things are happening." They have a national organization now, The Leadership Foundation. The action sheet proposes the following, "To improve the quality of educational materials in public schools... this is what you dol Determine if the books listed on the attached leaflet (or like books) are in your local high school library; then, contact, - by letter, phone, in person, boards of education members (county, city and state) .... County and city superintendents of schools... the governor of your state to use the prestige of his office ... your state legislators .... ask for a state wide policy of having the persons who select the library books to sign the originating request and of having a permanent record kept and ask for corrective legislation." A sample petition is included "to be forwarded to all public officials, beginning with the governor, to use their influence to see these needed corrections are made."

As the days go by, you ponder over and over and over again the questions of, how do you cope with people who would destroy one of our most precious liberties? How can you prevent yourself from getting mired down in hatred against them? They call us atheists, communists, perverts, dope addicts and intellectuals with a tone of scorn. Will you in turn call them ignorant, prudish, zealots? You know in your heart that name-calling only adds to the problem. Yet, the temptation is so very, very hard to resist. We are not dealing with a single type of individual but with a wide spectrum of personalities. One member of the Christian Action League may be a humble, God-fearing farmer in Hominy Valley; while another may be a Charlotte industrialist, sophisticated, wealthy and a man of considerable in- 
fluence. Since many of these individuals are tithers, the movement is "loaded" financially. To be frank, the leadership we have encountered has been unscrupulous, noisy, tough, uncompromising, unsmiling and untiring. Clothed in garments of selfrighteousness, some will stoop to a low level along the road of their holy crusade.

The name of the AFA is significant. They have one answer for all of America's problems - The Answer, how neat, how simple, one answer!

The tremendous power wielded by the clergy may be illustrated by an experience the psychologist had one day. He was fishing along the banks of the French Broad River. He had excellent luck. Along came two mountaineers both wearing wool hats. They ask if they may fish there too. They visit and talk about fishing. Then he asks their opinion about the book controversy. One man says he "trusts the opinion of the teachers." The other one says, "Oh no, I trust just one and that's Jesus. No I don't talk with Jesus but my pastor talks to Jesus and whatever he says Jesus says about it is where I put my trust."

Mark Butler in a letter to the editor has expressed a point of view regarding the freedom to read; it is entitled, "Books and People." "I am a 9th grader at T. C. Roberson High School who does a lot of reading and it seems strange to me that I have come across only one of these socalled filthy books. I think this is pretty good considering I have read over 50 books this year. Now, about Miss Solesbee's letter, she wants to have books thrown out of the school libraries. I thought the First Amendment said something about Freedom of the Press. Also I don't like the idea of censoring books for the public. I also think that when a person reads a book and sees only the cuss words or the parts which describe sexual intercourse that person is degenerate. About the passages which refer to homosexuality, sexual assault, murder, and other crimes, one simply has to learn how to cope with such problems." (signed) Mark Butler

May I urge that we have faith in the young people of America. They can learn to cope. For example, they did not ex- perience the deplorable depression of the thirties. They will not be lost in sin by reading the word "damn" on page 24 of The Grapes Of Wrath. Rather, will they be lead to a profound experiencing, a real feeling for the overwhelming problems of the Joad family as they leave their homestead in Oklahoma on their trek across the desert to the promised land of California. In this affluent society in which we live, I believe it is important that our youth should come to know what a struggle it was to live, just to stay alive, to go another painful mile along the way in that tragic era in America's history.

Yet, there are those in North Carolina today who would strike the match to the great literary works of all the ages. In the words of Smokey The Bear, "Only you can prevent a forest fire! ${ }^{\prime \prime}$

At long last you are in Winston-Salem, saying to your friends, "Thank you, thank you so very much for listening to what is for me the Buncombe County Case."

We Specialize in

\section{SCARCE OLD BOOKS}

- We'll Buy Them. We chase rare old titles from Murphy to Manteo - and pay well when we find one.

- We Sell Them - We know the market - we have a big stock and the chances are we can fill your tough order, prontol

- We Swap Them - If there is a North Carolina book that you need but can't afford, we'll arrange a swap for something in your pile of unsuitable gifts.

\section{THE OLD BOOK CORNER}
137 A East Rosemary Street
Chapel Hill, N. C. 27514
Tel. $919-942-5178$ 